\title{
Assessing significant harm to terrestrial ecosystems from contaminated land
}

\author{
R. Smith ${ }^{1 *}$, S.J.T. Pollard ${ }^{1}$, J.M. Weeks ${ }^{2}$ \& C.P. Nathanail ${ }^{3}$ \\ ${ }^{1}$ Cranfield University, Integrated Waste Management Centre, Cranfield University, School of \\ Industrial and Manufacturing Science, Building 61, Cranfield, Bedfordshire MK43 0AL, UK \\ ${ }^{2}$ The Centre for Environment, Fisheries \& Aquaculture Sciences, Pakefield Road, Lowestoft, \\ Suffolk, NR33 0HT, UK \\ ${ }^{3}$ School of Geography, The University of Nottingham, Nottingham NG7 2RD, UK \\ * Corresponding author: Tel: +44 (0)1234 754963; Fax: +44 (0)1234 751671; E-mail: $\overline{\text { r.smith1@ cranfield.ac.uk }}$
}

\begin{abstract}
Terrestrial ecosystem risk assessment by comparison with the aquatic discipline remains in its infancy yet is advancing quickly in response to increasing concerns surrounding soil quality and the sustainable use of soil. Several international frameworks have been developed during the last decade to aid decision makers as the need for scientifically derived tools for determining ecological risk from land contamination has been recognised. From the regulatory viewpoint, the priority is establishing what to protect in order to prevent ecological harm. This is a complex issue requiring clear objectives in a risk assessment context. The most important factor in assessing ecological harm is whether or not ecosystem function is altered as a result of land contamination and if it is, judging the significance. A consensus is developing that ecological risk assessment should aim to protect populations rather than individuals. This paper critically reviews and considers recent developments in risk assessment for terrestrial ecosystems and land contamination in the UK with emphasis on deriving a measure of ecological harm to assess ecosystem function. We seek to further justify the use of earthworms as a favoured indicator species for protecting ecological function. Guidance on how to measure harm in relation to ecological function is, however, still lacking.
\end{abstract}

Keywords: Ecological harm, ecosystem function, land contamination, risk assessment, environmental protection, earthworm 


\section{INTRODUCTION}

Ecosystem management has been described as a magnet for controversy (Lackey 1998), conflict and debate as exemplified by serious national aquatic ecosystem problems in the 1960s and 1970s (Ferguson et al. 1998). An ecosystem is defined as a community of organisms and their physical environment interacting as an ecological unit (Lincoln et al. 1998). Ecosystems are dynamic complex living systems subject to important continual and natural processes of change in response to various internal and external stresses. Exposure to soil contamination can be one such stress that can have consequences to terrestrial ecosystems e.g. the reduction of earthworm population size due to mortality or as more sensitive parameters, reduced growth and reproduction.

The type and severity of ecological impacts and effects governs the likelihood and rate of ecological recovery. Ecological change or harm caused by stressors such as contamination within an ecosystem will result in slower recovery than adaptation and evolutionary change might otherwise allow, possibly with maintenance of a degraded state (Whitford et al. 1999). There are various ways of describing land, the degree of contamination within it and the consequences for specified ecological receptors.

Whilst primitive civilisations have demonstrated respect for natural systems, the post industrial society has become separated from the nature and value of earth's life support systems until their disruption or loss highlighted their importance (Slobodkin 2000). Even as late as the early 1990s, authors (Spellerberg \& Minshull 1992) were bemoaning the poor quality of ecological inputs into environmental impact assessments. Though all ecosystems have been at some risk from human impacts for millennia, the use of chemicals has increased over time. It was only two decades ago that ecological risk analysis was promoted as a new concept (O'Neill et al. 1982) when laboratory toxicity data were extrapolated to field-scale aquatic ecosystems. Ecological risk assessment is inherently more complex (i.e. multi species) than human health risk assessment and ecologically relevant data are often based on aquatic systems (Scott-Fordsmand et al. 1996). The terrestrial ecosystem risk assessment discipline is advancing but is still in its infancy.

Risks are often characterised on the basis of individuals and so extrapolation is also required from the individual to population level. There are many reasons, other than scale, why extrapolation techniques are limited and these are reviewed elsewhere (Douben \& Siepel 1993; Forbes \& Forbes 1993; Suter 1993; Løkke 1994; Shore 1995; Spurgeon \& Hopkin 1995; Spurgeon 1997; Suter 1998; Forbes et al. 2001; van Beelen et al. 2001).

The monitoring of a species within an ecosystem can provide an indication of ecological harm. Some ecosystems are maintained for their importance and scientific interest $e$.g. in order to protect rare species or habitats that are often the basis of a site being designated. Designated sites are the basis of the Part IIA contaminated land legislative regime in the UK. Other ecosystems are considered to be more general e.g. farmland and contaminated sites that fall outside of Part IIA that may require management and remediation. Ecosystems evolve naturally due to the presence of niches that allow new species to thrive and others to decline. Thus through niche differentiation certain species may have advantages over others. Human intervention in the form of management is usually to the advantage of rare species. This implies that all species have a value, whether artificial or real and the value of rare species is often perceived to be higher than 'common' species even though the ecological value expressed as ecological function can be of equal or greater importance. 
Ecological effects may not be significant if ecological function is maintained. Early case studies of observed ecological effects were not necessarily related to harm or ecological function. For example, probable effects were noted on the evidence of metal contaminants found in organs of avian and mammalian species and densities of invertebrate species in soil litter were greatly reduced as a result of metal contamination from two zinc smelters in Pennsylvania, USA (Beyer et al. 1985). Another study demonstrated effects on two small mammals and two soil invertebrate species caused by fluoride contamination from an aluminium plant at Anglesey in North Wales (Walton 1986, 1987). Ecological effects finally became related to ecosystem function in the 1990s typified by published case studies on earthworm growth, reproduction, sexual development and early cocoon production affected by heavy metal contamination from zinc smelters in The Netherlands (Posthuma et al. 1994) and the UK (Spurgeon \& Hopkin 1996a,b; Spurgeon \& Hopkin 1999a).

The assessment of harm to terrestrial ecosystems from contaminated land is a main facet of the UK contaminated land regime. If ecological harm is to be prevented, understanding the behaviour and effects of contaminants in the environment is important and is a central aim in ecotoxicology (Forbes \& Kure 1997). The ability to predict this quantitatively is required to avoid harm. In the absence of an objective definition for terrestrial ecological quality (CLARINET 2001), the assessment of ecological effects and harm is difficult to establish. There is a scarcity of published case study information for terrestrial ecosystems against which to assess the ecological meaning of 'safe' concentrations (Posthuma 1997) and causal relationships between soil quality and their ecosystem functions still need to be demonstrated (Herrick 2000). Contemporary risk assessment methods do not suggest or identify consequences to a particular ecosystem if exposure exceeds defined 'safe' contaminant thresholds, other than that population responses are observed in the field (Posthuma 1997).

The extent of land contamination worldwide is considerable though estimates vary. In 1998 the European Environment Agency reported that over 300,000 potentially contaminated sites had been identified in Western Europe alone (Andersen 2000). This provides an indication of the scale of the problem though national estimates vary considerably, for example (Environment Agency 2000b; Royal Commission on Environmental Pollution 1996). In the UK, the historic assessment of land contamination (1970s to 1990s) has been based on defined 'trigger values' or reference values for individual contaminant concentrations in soil, for example the ICRCL values (Inter-Departmental Committee on the Redevelopment of Contaminated Land 1987). Other countries, including Germany, the Netherlands, Canada, Japan, Estonia and Bulgaria, have developed guideline values for assessing the extent or significance of soil contamination. There has been much concern that soil guideline values, as surrogates for assessing harm, are frequently misused through lack of understanding (Ferguson 1994). The use of reference values does not account for important ecological characteristics such as the severity of effect $e$.g. irreversibility and spatial or temporal extent. This restrictive approach is evolving into a combination of chemical, ecotoxicological and ecological approaches as scientific understanding develops. Part IIA of the Environmental Protection Act 1990 is the first UK legislation specifically to cover historic land contamination. Whilst Part IIA seeks to protect a wide range of receptors, the only ecological receptors protected are designated habitats and species e.g. particular species that are the basis of Sites of Special Scientific Interest (SSSIs). In restricting the legislation to designated receptors, the most sensitive, valuable or rare ecosystems should be protected. Other UK legislation, for example the Wildlife and Countryside Act 1981, also exists to protect such wildlife. However in some cases the long-term maintenance of a population or a species at any location may depend upon the sympathetic management of areas beyond the boundaries of a protected location (English Nature 2001). 


\section{LEGISLATIVE REGIME}

Natural soil is one of the key elements enabling life on earth (Achazi 2002) and justifiably soil is now protected in its own right. In 2002, in response to soil degradation concerns, the European Commission outlined a strategy for soil protection throughout the EU, putting soil protection on a par with water and air (European Commission 2002). In the UK there are many laws containing soil protection aspects including the Town and Country Planning Act 1990. The primary legislation for contaminated land in England and Wales is set out in Part IIA (S78A-S78YC of the Environmental Protection Act 1990, as inserted by Section 57 of the Environment Act 1995; Statutory Guidance contained in DETR Circular 02/2000 (Department of Environment Transport and the Regions 2000a); and the Contaminated Land (England) Regulations 2000 (Department of Environment Transport and the Regions 2000b). This new regime came into force in England on 1 April 2000 and is the first UK legislation to deal exclusively with land contamination. Part IIA is based on the polluter pays and risk management principles and it only applies to existing (historic) contaminated land not being dealt with under different legislative regimes such as Integrated Pollution Prevention and Control.

\section{Definition of contaminated land in the $U K$}

The legal definition of contaminated land is provided in statutory guidance contained in Section 78A(2) (Department of Environment Transport and the Regions 2000a) as any land which appears to the local authority in whose area it is situated to be in such a condition, by reason of substances in, on or under the land, that (a) significant harm is being caused or there is a significant possibility of such harm being caused; or $(b)$ pollution of controlled waters is being, or is likely to be caused... The new regime is profoundly restricted by the definition and is subject to interpretation. The regulatory regime set out in Part IIA involves a tiered approach that involves (a) problem identification, (b) risk assessment, (c) determination of appropriate remediation requirements, (d) consideration of costs, (e) establishment of who should pay and (f) implementation and remediation (Environment Agency 2000a). The Contaminated Land (England) Regulations 2000 (Department of Environment Transport and the Regions 2000b) set out further requirements, particularly in respect of the content of remediation notices.

\section{Designated areas}

Sites of national and sometimes international importance for nature conservation are notified as SSSIs by the Government's statutory conservation agencies (English Nature, Scottish Natural Heritage and the Countryside Council for Wales). SSSIs presently cover more than $7 \%$ of land in England and Wales and the protection of such sites for their wildlife value is a priority. Many SSSIs are showing damage or neglect; an assessment of SSSIs in England, Scotland and Wales indicated that in England, 58\% of SSSI land by area was in favourable or recovering condition, leaving $42 \%$ in unfavourable condition (English Nature 2003). Having established the principles of the ecological risk assessment in the context of the legislative regime, the basis of ecological risk assessment is highlighted below.

The identification and assessment of the likelihood of ecological harm for a particular site is not straightforward. There is the possibility that the remediation of a site defined as being contaminated under the Part IIA regime may compromise the survival of species that have adapted to the conditions at that site $e . g$. arsenic tolerance in earthworms at mine spoil sites in the UK (Langdon $e t$ 
al. 1999). In this scenario, the remediation activity itself may result in more harm that might have otherwise occurred by not carrying it out, thus compromising ecosystem function. The adaptation of species is valuable in contributing to biodiversity and equally biodiversity may diminish if that species is removed by remediation. Such issues must be considered when assessing the need for ecological protection.

\section{APPROACHES TO ECOLOGICAL RISK ASSESSMENT}

\section{Definitions}

A UK definition of ecological risk assessment is "an evaluation of the likelihood of adverse effects on organisms, populations, and communities from chemicals present in the environment" (Environment Agency 2003). This definition recognises that ecological effects can occur at different levels but it lacks specific reference to the need to maintain ecological function. The USEPA (United States Environmental Protection Agency 1998) similarly defines ecological risk assessment as "a process that evaluates the likelihood that adverse ecological effects may occur or are occurring as a result of exposure to one or more stressors".

\section{International approaches}

A review of international approaches to ecological risk assessment demonstrates that similar approaches are taken, usually on a tiered basis, and that different levels of protection or tolerable effects may be derived. Generally, most countries use generic guidelines for a first screening of ecological risk (Ferguson et al. 1998). The basis, limitations and benefits of the approaches in selected countries are presented in Table 1. Many countries, including the UK, are only at the stage of developing or agreeing suitable frameworks. The need for a common European framework in the form of a conceptual model has been identified and formulated (CLARINET 2001 \& Crommentuijn et al. 2001). The approach adopted in the Environment Agency's consultation document on a framework for ecological risk assessment (Environment Agency 2003), follows the conventional approach to environmental risk assessment and management in the UK, as contained in revised departmental guidelines. This provides a tiered framework for characterising the source, pathway, receptor relationship (Department of Environment Transport and the Regions et al. 2000). All three components of a linkage must be present for a risk to exist.

\section{Ecological risk assessment requirements}

An ecological risk assessment has two fundamental requirements on a site-specific basis; information on exposure and information on an effect(s). Exposure data typically consists of pore water, soil quality and tissue concentrations in the receptor, and must include ambient reference or control areas to allow for the presence of naturally elevated "contaminants" e.g. arsenic in parts of the south west of the UK. In earthworms, organic chemicals are taken up through the skin (Jager et al. 2003) and dermal uptake has been separated from exposure arising from ingestion in the gut. The ingestion route becomes preferential for hydrophobic contaminants (Jager et al. 2003) such as benzene, toluene, ethylene, BTEX compounds, chlorinated solvents and nitrotoluene contaminants. A fundamental concept of ecological risk assessment is that increased exposure time increases toxicity or decreases the lethal concentration (usually $\mathrm{LC}_{50}$, defined as the lethal concentration to $50 \%$ of the organisms over a given time period in an acute toxicity study). 


\section{TRIAD approach}

Ecological risk assessment requires an integrated approach based on a number of measures and criteria (Rutgers et al. 2000). The triad approach has often been adopted as a basis for interfacing chemical, toxicological and ecological information (Chapman 1986; Chapman 1992; Breure \& Peijnenburg 2003). In this approach, toxicology is assessed by the use of bioassays as experiments in which organisms are exposed to site-specific field samples and ecological responses are observed under standard conditions (van Straalen 2002) and normalised to reference data. This approach is likely to be adopted in England and Wales (Environment Agency 2003).

\section{No observed effect concentrations}

Ecological risk assessment is often based on the standardised No Observed Effect Concentration (NOEC) as the toxicity input parameter (Posthuma 1997). NOEC is a reference level derived as the concentration at which there is no toxicological effect (acute or chronic though usually chronic) on an ecologically relevant characteristic (typically reproduction) for a chosen receptor after different doses (usually of individual chemicals) have been applied, usually in the laboratory. Organisms are more sensitive to lower NOECs in a given soil. Legislation in the Netherlands is the most advanced in Europe with regard to ecological risk assessment for contaminated land and the approach of the Dutch Soil Protection Act (Netherlands Ministry of Housing Spatial Planning and the Environment 1994) is to maintain and restore the multifunctionality of soil. The role of ecology is defined by use of the $\mathrm{HC}_{50}$ whereby the hazardous concentration for $50 \%$ of the geometrical mean for all available NOECs (assuming log normal distribution) is applied. A procedure for performing population-level ecological risk assessments was required at the Federal level in Oregon, USA (Hope \& Peterson 2000). There, the acceptable risk is defined legislatively as $10 \%$ or less chance that $20 \%$ or more of the total local population would receive an exposure greater than the toxicity reference value for a given substance. As with the Netherlands approach, the toxicity reference value for populations of ecological receptors is defined as the $\mathrm{LC}_{50}$. The use of NOEC is a good starting point but it is limited as NOECs are based on individual substances rather than chemical mixtures and actively growing organisms are most sensitive to contaminants, thereby making the age of organism an important factor. Even protection of $95 \%$ of the species is also unlikely to protect rare or indicator species (Forbes \& Forbes 1993; Hopkin et al. 1993). The determination of unacceptable and acceptable risk for land contamination in the UK has not been tested and case law is likely to be important in setting a precedent.

\section{HARM TO TERRESTRIAL ECOSYSTEM RECEPTORS}

Table A of the DETR Circular (Department of Environment Transport and the Regions 2000a) specifies the receptors to be protected under Part IIA. The terrestrial ecological receptors in Table A are presented in Table 2. Designated areas are defined in DETR Circular 02/2000 which defines significant harm to terrestrial ecosystem receptors amongst others. Significant harm is described as that which results in an irreversible or other substantial adverse change in the functioning of the ecological system... or that which affects any species of special interest... and which endangers the long-term maintenance of the population of that species at that location.

Ecological harm and its assessment is a general underpinning concept of the Part IIA legislation and this section therefore focuses on Part IIA receptors. This concept requires development in order to define how to measure harm in relation to ecological function. Information likely to be required for 
a site-specific risk assessment to determine harm is presented in Table 3. The de minimus ecological risk can be a lack of evidence for an impact on selected species or ecosystem function. Other authors suggest a $20 \%$ level as the threshold for a de minimus level of significant ecological effect (Suter et al. 2000) beyond which restoration is required.

Harm to terrestrial ecosystems can be assessed by considering soil quality. Biological indicators of soil quality include nitrogen and carbon availability, leaf litter decomposition and soil fauna populations, including arthropods and invertebrates. Whilst the measurement of these indicators is readily achievable, their contribution towards the definition of contaminated land and ecological harm is uncertain. In calculating organism exposure, the critical factor is likely to be the amount of soil ingestion. Soil quality indicators are important to ensure maintenance of soil function for current and future land uses. Historically, reliance has been placed on assessing soil quality based on individual chemical data without considering synergistic or additive effects.

Assessment of soil quality within a protected area of ecological value can indicate the nature and spatial distribution of contamination present. Soil quality is defined as the capacity of soil to function as a vital living system to sustain biological productivity, promote environmental quality and maintain plant and animal health within natural or managed ecosystem boundaries and including the support of human health and habitation (Karlen et al. 1997). In the absence of a European standard for soil quality many countries have developed their own standards and guidance based around that of the USEPA (United States Environmental Protection Agency 1998). A common approach is to start with the endpoint, for example develop guideline values based on landuse. This is the basis of the Netherlands approach (van de Leemkule et al. 1999; van Hesteren et al. 1999; van Wensem et al. 2000; van Wensem \& Vegter 1998). The use of such values is questionable when remediation is initiated (Crommentuijn et al. 2000), since if soil quality shows marginal exceedance, remediation cannot be justified on the basis that costs outweigh the benefits.

\section{Ecological protection and conservation: individuals or populations?}

There are different ecological risk assessment endpoints, the selection of which depends on the levels of biological organisation in question i.e. individual, population, community and entire ecosystem. There is increasing scientific and policy consensus in the UK (Department of Environment Transport and the Regions 2000a) that ecological risk assessment should aim to protect populations rather than individuals, for example against loss of species diversity (Posthuma 1997). Ecosystems do not exist in the same way that organisms (as individuals) exist (Calow 2000). Population effects are typically assessed by quantifying abundance, mortality and reproduction. With the exception of endangered species which are protected as individuals, most species decisions are based on population level effects (Suter et al. 2000).

Reviews of terrestrial population models for ecological risk assessment have been carried out (Emlen 1989; Hope 1995) including the role of such models (Barnthouse 1992). These reviews concluded that the most easily accessible and appropriate endpoints for population assessment are pseudoextinction (the probability of a population falling below a predetermined fraction of its undisturbed level) and temporal mean population density. Effective conservation measures require knowledge of factors affecting population persistence and the magnitude of their effects (Fahrig 2001). Case studies have demonstrated population level effects along pollution gradients. These effects can be significant, for example reduced cocoon production rates and reduced growth rates evident in earthworms around the Avonmouth smelter in the UK (Spurgeon 1997). Though no 
earthworm mortality was evident, it was probable that zinc was affecting earthworm reproduction, a more sensitive indicator and therefore population viability close to the smelter.

Modelled simulations of habitat loss and species extinction (Akçakaya 2001) suggest that habitat preservation and restoration is the highest priority for ecosystem protection. The prediction of extinction thresholds requires organism movement rates. Conservation strategies should consider the whole landscape quality, not just the protected habitat, since most ecosystem functions are spatially and temporally dependent (Herrick 2000; Fahrig 2001). Critical ecosystems are those with high ecological diversity, potential for long-term sustainability and presence of relic or native communities (Noss 2000).

\section{Significant harm and significant possibility of significant harm}

Assessing the significance of risk is the final stage of the risk assessment process, following hazard identification and identification, magnitude and probability of the consequences (Department of Environment Transport and the Regions et al. 2000). For ecosystems this is defined as being when growth, reproduction, or mortality is adversely affected, such that the survival of the population/community/species is threatened (Environment Agency 2003). Species composition may change naturally whilst such functions remain unaffected. The importance of maintaining a high level of ecological biodiversity is uncertain, though an ecosystem does not need to be highly diverse in order to maintain ecological function.

\section{Exposure assessment}

Exposure represents the probability of harm that can be measured by a dose response relationship or by bioavailability. Determining the choice of receptor is crucial and it requires careful consideration. Designated areas may require the consideration of harm that affects any species of special interest. A primary assumption is that the habitat determines which and how many receptors are exposed. Assuming that the main objective is to protect, evaluate or measure habitat function, species with a high sensitivity to suspected contaminants are required.

The USEPA use six criteria for exposure assessment (United States Environmental Protection Agency 1998). These are (1) how exposure occurs i.e. pathway analysis; (2) what is exposed i.e. receptor analysis; (3) quantifying the amount of exposure spatially and temporally; (4) variability of exposure; (5) uncertainty of exposure estimates; and (6) probability of exposure i.e. risk assessment.

The duration of exposure can be important and shorter-term exposure may be more significant to species of low ecological relevance. If the relevance becomes higher then the exposure needs to be longer-term. This relationship also helps understand where the ecological response lies.

\section{Effects assessment}

The effect represents the consequences of harm; contaminant availability does not equal harm. The possibility of significant harm is crucial but is subject to interpretation and definition. Definitions of harm must be quantified in order to determine if a given contaminated land site is contaminated 
land under Part IIA. Ecological effects data typically takes into account organism, species or population parameters such as fecundity, adult survival, reproduction and population growth.

There are four conventional biological measures that can be used to demonstrate whether a sourcepathway-target relationship constitutes significant harm, all of which have the ability to describe biological organisms or ecosystem components chemically. Biomarkers and toxicity tests are indirect measures and critical body residues and bioaccumulation are direct measures.

Ecosystem effect indicators are a promising way of portraying human influence on ecosystems, if sufficient information is provided for decisions to be made (Merkle \& Kaupenjohann 2000). Whilst ecosystem effects indicators can be developed (Figure 1) there is always a need to use indigenous communities.

Assessment of ecological harm must have predictive capability if irreversible effects are to be prevented. However, response to contamination is not entirely predictable (Noss 1990) and ecosystem sensitivity undoubtedly varies. This reiterates the need for an approach combining predictive modelling and monitoring.

\section{USE OF EARTHWORMS FOR ASSESSING ECOLOGICAL FUNCTION AND HARM}

\section{Ecological relevance of soil invertebrates}

The value of soil invertebrates other than earthworms, such as nematodes, mites and springtails is high and is related to their ecological role, e.g. litter decomposers regulate energy flow and nutrient cycles. Many soil invertebrates can be used for monitoring the status of soil ecology and the selection of species for a particular study should be given careful thought. Earthworms are a preferred indicator because key ecological functions are adversely affected by their absence. Nematodes are the most abundant ecologically relevant species, followed by mites and then springtails. Composition of nematode communities in soil may indicate levels of soil contamination (Lau et al. 1997). Critical factors in selecting species as indicators of harm to an ecosystem are their ecological relevance, ecological importance and sensitivity. Other less important factors include abundance, ubiquity, ability to survive in different soil conditions and ability to be exposed to multiple pathways.

Contaminants can be resistant to decomposition processes, e.g. polyaromatic hydrocarbons (PAHs), and therefore they accumulate in soil (van Brummelen et al. 1996). Soil invertebrates easily become exposed to such contaminants, potentially affecting their ecological functioning. Indicator species may change temporally so it is important to identify the species that are responsible for maintaining function. Earthworms and woodlice are ecologically relevant soil invertebrate fauna and as such are good indicator species. However, the use of soil invertebrate bioindicators and the measurement of toxicity endpoints such as mortality and biomass loss require careful validation by field studies and should not simply be reliant on extrapolation from laboratory data. 


\section{Why earthworms?}

Earthworms have been used increasingly for ecological risk assessment since the introduction of international standards including the OECD acute earthworm toxicity test in 1984 (Spurgeon et al. 2003). There are many reasons why earthworms are widely used and they are now regarded as a model organism. Earthworm communities offer many advantages for assessing soil quality (Urzelai et al. 2000) and they are the favoured indicator species in the Netherlands.

Earthworms are engineers (Lawton 1994) and as Darwin intimated, they are like an unacknowledged elemental force (Phillips 1999). Earthworms are arguably the most important soil biota in maintaining soil structure, function and fertility (Edwards 2004) and they have an important role in contaminant transfer through the food chain with potential for predatory secondary poisoning via bioaccumulation and food chain transfer (Spurgeon \& Hopkin 1996c). The contribution of earthworms to soil fertility can be considerable (Killham 1994) and earthworms are intimately involved in organic matter decomposition (for example of surface leaf litter and the remineralisation and humification of organic matter). They also contribute to soil aeration and have large direct effects on nitrogen cycling (Killham 1994; Forbes \& Kure 1997). Furthermore earthworms are likely to have long exposure periods to contaminants within land, due to their low mobility, increasing the likelihood of being able to establish effects in the field. Earthworms are also a preferred species for ecological risk assessment because they are more highly exposed to soil contaminants through ingestion and dermal contact than other soil and leaf litter invertebrates (Ma 1994).

Earthworms are intrinsically linked and are therefore vital to ecosystem function. As a receptor, earthworms can be regarded as a surrogate ecosystem, an approach advocated for the conservation of aquatic target taxa and communities (Hitt \& Frissell 2004). Various sensitive endpoints, such as biomass change and reproduction, have been identified in earthworm toxicology (Schaefer 2003). The main exposure route for earthworms and most other soil invertebrates is pore water uptake through the dermis and pore water concentrations are a good measure of bioavailability (Naidu et al. 2000). Field contaminant exposure resulting in harm to earthworms has been demonstrated, e.g. four metals released from the Avonmouth smelter $(\mathrm{Cd}, \mathrm{Cu}, \mathrm{Pb}, \mathrm{Zn})$, of which zinc is the limiting factor for earthworm distribution (Spurgeon \& Hopkin 1996b).

\section{Earthworm classification and ecology}

Different classification schemes exist for categorising earthworm communities into functional groupings according to soil properties such as litter-dwellers (epigeic), mineral soil feeders and dwellers (endogeic) or permanent/semi-permanent soil burrowers feeding on surface-litter (anecic) (Neilson et al. 2000; Edwards 2004). The ecology of earthworm species needs to be accounted for when undertaking a risk assessment as species sensitivity to contamination varies, particularly with regard to metal accumulation, for example (Morgan \& Morgan 1999). Cadmium in particular is strongly accumulated by earthworms (Mariño \& Morgan 1999). The risk of bioaccumulation can be twofold; risk to earthworms and risk to species higher up the food chain. Thus, it may be appropriate when undertaking a risk assessment to select the most vulnerable species in order to derive a conservative risk estimate. 


\section{Contaminant exposure studies}

In exposure studies most organisms, including soil biota, are ordinarily exposed to different types and concentrations of contaminants. During the last decade earthworms have been used extensively both in the laboratory and increasingly in the field to assess sub-lethal toxicity of different soil contaminants. Earthworm growth, reproduction and mortality have been recorded in response to different exposure levels and contaminants, most commonly for metals, pesticides, PAHs and explosives (see Table 4 for references to selected field exposure data).

Several studies of earthworm exposure to different soil contaminants in the field and the laboratory have been published that demonstrate differing degrees of harm, either as a result of direct contact with the soil, or exposure to free metal concentration in the soil pore water. International test methods e.g. OECD, recommend the use of the earthworm species Eisenia foetida and E. andrei, though Lumbricus species are also widely used by researchers. Consequently the earthworm species Eisenia fetida and Lumbricus terrestris have been researched more comprehensively than other species (Scott-Fordsmand et al. 2000).

Enzmyic inhibition in earthworms is a sensitive parameter that is increasing in use. From the literature we can see for example, that lead has been shown to inhibit certain enzymes in Eisenia fetida andrei and this inhibition is generally dependent on the dose or duration of exposure; significant changes were detected at exposure to $30 \mathrm{mg} \mathrm{kg}^{-1}$ (Saint-Denis et al. 2001). This concentration is considerably less than the maximum permissible concentrations for soil in selected countries identified in Table 1. Body concentrations of metals, that are strongly accumulated in earthworms, may be more representative of bioavailability and toxicity than the conventional total chemical or extractable soil concentrations (Mariño \& Morgan 1999). Factors including soil texture and structure are responsible for contaminant migration through the soil matrix. There is some evidence for the distribution of soil contamination also being affected by earthworm activity and behaviour. Farenhorst et al. (2000) studied atrazine in laboratory microcosms in which earthworms were shown to influence the distribution of atrazine in the soil matrix. In soil matrices where earthworms were absent, $65 \%$ of the atrazine applied remained within the top $4 \mathrm{~cm}$ surface layer. In soil profiles where earthworms were added after atrazine application, $60 \%$ of the atrazine applied was translocated below $4 \mathrm{~cm}$ by feeding activity. Toxicity of the explosive 2,4,6-trinitrotoluene and of octahydro-1,3,5,7-tetrazocine (HMX) have been determined in soil to the earthworm Eisenia Andrei (Robidoux et al. 1999; Robidoux et al. 2001). Even though HMX has limited water solubility, a number of sublethal effects were identified including growth inhibition and reproductive effects, suggesting the cause was direct contact. These effects were present even at the lowest concentration tested $\left(\sim 280 \mathrm{mg} \mathrm{kg}^{-1}\right)$. Lethality was not demonstrated, even at the highest concentration tested $\left(\sim 2500 \mathrm{mg} \mathrm{kg}^{-1}\right)$. Soil guideline values for explosive substances do not exist so a direct comparison is not possible.

Soil is the major sink for PAHs in the environment (van Brummelen et al. 1996). PAH concentrations in the earthworm species Lumbricus rebellus and the isopods Porcellio scaber, Oniscus asellus and Philoscia muscorum, were measured along a pollution gradient from a blast furnace plant (van Brummelen et al. 1996). Species-specific profiles for PAH contamination have been identified in a soil contamination gradient near a blast furnace plant in the Netherlands; species profiles were found to be dependent on feeding behaviour, whether fragmentation or leaf litter. 


\section{DISCUSSION}

Preservation of function is of most significance to ecosystem protection. The hypothesis that, loss of indicator species does not impact on soil ecosystem function, requires testing in order to define significant harm for Part IIA that may also derive action levels for remediation, according to future land use. This approach must serve as an ecological indicator by having predictive capability and the modelled prediction must be measurable whilst being sensitive to change. Although several species are used as indicators for ecosystem protection, the scientific rationale for their selection is not always apparent. Current guideline values for assessing soil quality are frequently misused and should be used cautiously and sparingly. For example, guideline values for lead in selected European countries were up to one order of magnitude in excess of the level at which 'significant changes' occurred in Eisenia fetida andrei at the biochemical level (Saint-Denis et al. 2001).

Priorities for terrestrial ecosystem risk assessment and land contamination include detecting ecological harm, developing modelling capability to assess terrestrial ecosystem function and accepting uncertainty. Long-term studies which include control sites are required. Collaboration and sharing of knowledge is needed if consensus and credibility is to be achieved. In the absence of a full model of generic risk assessment, careful detailed quantitative risk assessments ensure a precautionary approach is taken. The cumulative effect of the uncertainty surrounding these assessments should not be underestimated. Links between specific ecological harm and the monitoring of individual species have yet to be made. Studies that demonstrate ecological harm resulting from the presence of contamination where there is a lack of earthworms would further justify the use of earthworms as indicator species.

Available evidence to date suggests that most contaminated land in the UK, as determined using the legal definition, will be identified mainly on the basis of risks or harm to receptors other than terrestrial ecosystems. A survey carried out for the year 2001 identified categories of risk and remediation required at 68 contaminated land sites in the UK that had been remediated. Of these, the protection of ecologically sensitive receptors was a factor at only $7 \%$ of sites, and protection of human health at $91 \%$ of sites (Nathanail et al. 2003). This trend is likely to continue (Quint 2001).

\section{CONCLUSIONS}

Internationally, because of a scarcity of empirical studies that show an elevated risk to terrestrial ecosystems from land contamination, countries have relied on generic standards that are not necessarily risk based or scientifically derived. The literature demonstrates that there is a paradigm shift taking place towards developing risk assessment procedures for terrestrial ecosystems and the pace of change is rapid.

The use of earthworms as surrogate species for terrestrial ecosystem risk assessment requires validation and a comprehensive understanding of the relationship between the functional groups is needed. Future research must also critically investigate the extent to which current risk assessment tools, techniques, frameworks and ecotoxicological tests can inform decisions about the significant possibility of significant harm with respect to ecological harm and land contamination under Part IIA (Department of Environment Transport and the Regions 2000a). Ecological risk assessment must focus on the determination of ecological harm measured by ecological effects from contaminant mixtures. Ecosystem function is largely dependent on soil processes and therefore 
function - for which earthworms are surrogate model organisms - represents a viable measure of ecological harm. This concept has not been widely applied to ecological risk assessment and it requires further development.

\section{ACKNOWLEDGEMENTS}

The authors wish to thank the two peer reviewers in providing helpful comments.

\section{REFERENCES}

Achazi RK 2002. Invertebrates in risk assessment: development of a test battery and of short term biotests for ecological risk assessment of soil. Journal of Soils \& Sediments 2, 174-178.

Akçakaya HR 2001. Linking population-level risk assessment with landscape and habitat models. The Science of The Total Environment 274, 283-291.

Andersen JN ed 2000. Management of contaminated sites and land in Central and Eastern Europe. Danish Environmental Protection Agency.

Barnthouse LW 1992. The role of models in ecological risk assessment: a 1990's perspective. Environmental Toxicology and Chemistry 11, 1751-1760.

Benker EB Meyers-Schöne L \& Nagy M 2000. Ecological risk-based cleanup goals for the protection of terrestrial receptors. Contaminated Site Remediation: From Source Zones to Ecosystems, ed CD Johnston, 4-8 December 2000, Melbourne, Australia. Vol.1, pp 109-116.

Beyer WN Chaney RL \& Mulhern BM 1982. Heavy metal concentration in earthworms from soil amended with sewage sludge. Journal of Environmental Quality 11, 381-385.

Beyer WN Pattee OH Sileo L Hoffman DJ \& Mulhern BM 1985. Metal contamination in wildlife living near two zinc smelters. Environmental Pollution Series A 38, 63-86.

Beyer WN Hensler G \& Moore J 1987. Relation of $\mathrm{pH}$ and other soil variables to concentrations of $\mathrm{Pb}, \mathrm{Cu}, \mathrm{Zn}$, and Se in earthworms. Pedobiologia 30, 172-187.

Breure T \& Peijnenburg W 2003. Developments in soil protection in The Netherlands. Journal of Soils \& Sediments 3, 248-249.

Calow P 2000. Critics of ecosystem health misrepresented. Ecosystem Health 6, 3-4.

Canadian Council of Ministers of the Environment 1998. Development and application of soil quality guidelines within the CCME framework for contaminated site assessment and remediation. 9 February 1998.

Chapman P 1992. Sediment quality triad approach. In: Sediment classification methods compendium. EPA 823-R-92-006. September 1992. pp 10.1-10.18.

Chapman PM 1986. Sediment quality criteria from the sediment quality TRIAD: an example.

Environmental Toxicology and Chemistry 5, 957-964. 
CLARINET 2001. Ecological requirements for land reuse. Clarinet Working Group 5.

Contaminated Land Rehabilitation Network for Environmental Technologies in Europe. 2 May 2001. http://www.clarinet.at/clarinet/ecology.htm

Corp N \& Morgan AJ 1991. Accumulation of heavy metals from polluted soils by the earthworm, Lumbricus rubellus: can laboratory exposure of 'control' worms reduce biomonitoring problems? Environmental Pollution 74, 39-52.

Crommentuijn T Bierkens J Herrchen M Jensen J Loibner AP Schelwald R van Wensem J Rutgers M \& Weeks J 2001. Ecological risk assessment for contaminated sites in Europe - ecorisk conclusions. In: Sustainable Management of Contaminated Land, Proceedings of the CLARINET Final Conference, 21-22 June 2001, Vienna, Austria.

http://www.clarinet.at/library/proceedings_finalconf.pdf

Crommentuijn T Polder M Sijm D de Bruijn J \& van de Plassche E 2000. Evaluation of the Dutch environmental risk limits for metals by application of the applied risk approach. Environmental Toxicology and Chemistry 19, 1692-1701.

Crommentuijn T Polder MD \& van de Plassche EJ 1997. Maximum permissible concentrations and negligible concentrations for metals, taking background concentrations into account. National Institute of Public Health and the Environment, Bilthoven, The Netherlands, Report No. 601501 001. October 1997.

Department of Environment Transport and the Regions 2000a. Environmental Protection Act 1990: Part IIA Contaminated Land. The Stationery Office, DETR Circular 02/2000. http://www.tso.co.uk/

Department of Environment Transport and the Regions 2000b. The Contaminated Land (England) Regulations 2000. Statutory Instrument 2000 No.227: The Stationery Office. http://www.opsi.gov.uk/si/si2000/20000227.htm

Department of Environment Transport and the Regions Environment Agency \& Institute for Environment and Health 2000. Guidelines for environmental risk assessment and management. Revised Departmental Guidance. The Stationery Office London. July 2000. http://www.defra.gov.uk/environment/risk/eramguide/

Douben PET \& Siepel H 1993. Extrapolation from laboratory to field and from individual to populations: pitfalls to avoid. Science of the Total Environment Supplement 1025-1036.

Edwards CA 2004. Earthworm ecology, CRC Press, Second edition.

Emlen JM 1989. Terrestrial population models for ecological risk assessment: a state-of- the-art review. Environmental Toxicology and Chemistry 8, 831-842.

Emmerling C Krause K \& Schroder D 1997. The use of earthworms in monitoring soil pollution by heavy metals. Pflanzenernahr: Bodenk 160, 33-39.

English Nature 2001. Advice to local teams on contaminated land; Environmental Protection Act, 1990, Part IIA. Guidance note 1: contaminated land: the nature conservancy value of 'eco-receptor' sites and English Nature's role in providing advice. Northminster House, Peterborough PE1 1UA, UK.

Environment Agency 1999. Biological stress indicators of contaminated land: ecological assessment of contaminated land using earthworm biomarkers. R\&D Technical Report P311. Waterside Drive, Aztec West, Almondsbury, Bristol BS32 4UD, UK. 
English Nature 2003. England's best wildlife and geological sites - The condition of Sites of Special Scientific Interest in England in 2003. Northminster House, Peterborough PE1 1UA, UK.

Environment Agency 2000a. Part IIA EPA, 1990 (England) Process handbook. Waterside Drive, Aztec West, Almondsbury, Bristol BS32 4UD, UK. EAS/2703/2/1/Version 3.2. 26 May 2000.

Environment Agency 2000b. The state of the environment of England and Wales: the land. Waterside Drive, Aztec West, Almondsbury, Bristol BS32 4UD, UK.

Environment Agency 2003. Ecological risk assessment: a public consultation on a framework and methods for assessing harm to ecosystems from contaminants in soil. Waterside Drive, Aztec West, Almondsbury, Bristol BS32 4UD, UK. December 2003.

European Commission 2002. Towards a thematic strategy for soil protection. COM(2002) 179 final. Brussels. http://europa.eu.int/comm/environment/soil/index.htm

Faber JH 1998. Ecological risks of soil pollution. Technical Soil Protection Committee (TCB) Report. P.O. Box 30947, 2500 GX, The Hague, The Netherlands. February 1998.

Fahrig L 2001. How much habitat is enough? Biological Conservation 100, 65-74.

Farenhorst A Topp E Bowman BT \& Tomlin AD 2000. Earthworms and the dissipation and distribution of atrazine in the soil profile. Soil Biology and Biochemistry 32, 23-33.

Ferguson CD \& Denner J 1994. Developing guideline (trigger) values for contaminants in soil: underlying risk analysis and risk management concepts. Land Contamination \& Reclamation 2, $117-123$.

Ferguson C Darmendrail D Freier K Jensen BK Jensen J Kasamas H Urzelai A \& Vegter J 1998. Risk assessment for contaminated sites in Europe: Volume 1 Scientific basis. Nottingham, LQM Press. ISBN 0953309002.

Forbes TL \& Forbes VE 1993. A critique of the use of distribution-based extrapolation models in ecotoxicity. Functional Ecology 7, 249-254.

Forbes TL \& Kure LK 1997. Linking structure and function in marine sedimentary and terrestrial soil ecosystems: implications for extrapolation from the laboratory to the field. In: Ecological risk assessment of contaminants in soil, eds NM van Straalen \& H Løkke, Chapman \& Hall, London, Ecotoxicology Series 5, 127-156.

Forbes VE Calow P \& Sibly RM 2001. Are current species extrapolation models a good basis for ecological risk assessment? Environmental Toxicology and Chemistry 20, 442-447.

Hendricks AJ Ma W-C Brouns JJ de Ruiter-Dijkman EM \& Gast R 1995. Modelling and monitoring organochlorine and heavy metal accumulation in soils, earthworms, and shrews in Rhine Delta floodplains. Archives of Environmental Contamination and Toxicology 29,115-127.

Herrick JE 2000. Soil quality: an indicator of sustainable land management? Applied Soil Ecology $15,75-83$.

Hitt NP \& Frissell CA 2004. A case study of surrogate species in aquatic conservation planning. Aquatic Conservation: Marine and Freshwater Ecosystems 14, 625-633. 
Hope BK 1995. A review of models for estimating terrestrial ecological receptor exposure to chemical contaminants. Chemosphere 30, 2267-2287.

Hope BK \& Peterson JA 2000. A procedure for performing population-level ecological risk assessments. Environmental Management 25, 281-289.

Hopkin SP Jones DT \& Dietrich D 1993. The isopod Porcellio scaber as a monitor of the bioavailability of metals in terrestrial ecosystems: towards a global 'woodlouse watch' scheme. Science of the Total Environment Supplement, 357-365.

Inter-Departmental Committee on the Redevelopment of Contaminated Land (ICRCL) 1987. Guidance on the assessment and redevelopment of contaminated land. 59/83 (2nd Edition) London.

Jager T Fleuren RHLJ Hogendoorn EA \& de Korte G 2003. Elucidating the routes of exposure for organic chemicals in the earthworm, Eisenia andrei (Oligochaeta). Environmental Science and Technology 37, $3399-3404$.

Karlen DL Mausbach MJ Doran JW Cline RG Harris RF \& Schuman GE 1997. Soil quality: a concept, definition, and framework for evaluation. Soil Science Society of America Journal 61, 410.

Killham K 1994. Soil ecology. Cambridge University Press.

Lackey RT 1998. Seven pillars of ecosystem management. Landscape and Urban Planning 40, 2130 .

Langdon CJ Piearce TG Black S \& Semple KT 1999. Resistance to arsenic-toxicity in a population of the earthworm Lumbricus rubellus. Soil Biology and Biochemistry, 31, 1963-1967.

Langdon CJ Piearce TG Meharg AA \& Semple KT 2001. Resistance to copper toxicity in populations of the earthworms Lumbricus rubellus and Dendrodrilus rubidus from contaminated mine wastes. Environmental Toxicology and Chemistry 20, 2336-2341.

Lau SS Fuller ME Ferris H Venette RC \& Scow KM 1997. Development and testing of an assay for soil ecosystem health using the bacterial-feeding nematode Cruznema tripartitum. Ecotoxicology and Environmental Safety 36, 133-139.

Lawton JH 1994. What do species do in ecosystems? Oikos 71, 367-374.

Lincoln R Boxshall G \& Clark P 1998. A dictionary of ecology, evolution and systematics, Cambridge University Press, Second edition.

Ma W-C 1982. The influence of soil properties and worm-related factors on the concentration of heavy metals in earthworms. Pedobiologia 24, 109-119.

Ma W-C 1994. Methodological principles of using small mammals for ecological hazard assessment of chemical soil pollution, with examples on cadmium and lead. In: Ecotoxicology of soil organisms, eds MH Donker H Eijsackers \& F Heimbach, Lewis Publishers (Setac Special Publications Series), Boca Raton, Florida pp 357-371.

Ma W-C Edelman T van Beersum I \& Jans T 1983. Uptake of cadmium, zinc, lead, and copper by earthworms near a zinc-smelting complex: influence of soil $\mathrm{pH}$ and organic matter. Bulletin of Environmental Contamination and Toxicology 30, 424-427. 
Mariño F \& Morgan AJ 1999. The time-course of metal (Ca, Cd, Cu, Pb, Zn) accumulation from a contaminated soil by three populations of the earthworm, Lumbricus rubellus. Applied Soil Ecology $12,169-177$.

Merkle A \& Kaupenjohann M 2000. Development of ecosystem effect indicators. Third SETAC World Congress, 21-25 May 2000, Brighton, UK. SETAC Europe, Av. de la Toison d'Or 67 B-1060 Brussels, Belgium.

Morgan JE \& Morgan AJ 1999. The accumulation of metals ( $\mathrm{Cd}, \mathrm{Cu}, \mathrm{Pb}, \mathrm{Zn}$ and $\mathrm{Ca}$ ) by two ecologically contrasting earthworm species (Lumbricus rubellus and Aporrectodea caliginosa): implications for ecotoxicological testing. Applied Soil Ecology 13, 9-20.

Naidu R Megharaj M Krishnamurti GSR Vig K \& Kookana RS 2000. Bioavailability, definition and analytical techniques for assessment and remediation of contaminated (inorganic and organic) soils. Contaminated Site Remediation: From Source Zones to Ecosystems, ed CD Johnston, Melbourne, Australia. 4-8 December 2000. Vol. 1, pp 283-289.

Nathanail CP Guess P Yardley R \& Ogden R 2003. Review of remediation practice in the UK during 2001. First Faraday, Research Report No. 1. http://www.firstfaraday.com/randd.htm

Neilson R Boag B \& Smith M 2000. Earthworm $\delta^{13} \mathrm{C}$ and $\delta^{15} \mathrm{~N}$ analyses suggest that putative functional classifications of earthworms are site-specific and may also indicate habitat diversity. Soil Biology and Biochemistry 32, 1053-1061.

Netherlands Ministry of Housing Spatial Planning and the Environment 1994. Soil Protection Act 1994. P.O. Box 20951, 2500 EZ Den Haag, The Netherlands.

Netherlands Ministry of Housing Spatial Planning and the Environment 2000. Circular on target values and intervention values for soil remediation DBO/1999226863. P.O. Box 20951, $2500 \mathrm{EZ}$ Den Haag, The Netherlands.

Neuhauser EF Cukic ZV Malecki MR Loehr RC \& Durkin PR 1995. Bioconcentration and biokinetics of heavy-metals in the earthworm. Environmental Pollution 89, 293-301.

Noss R 1990. Indicators for monitoring biodiversity: a hierarchial approach. Conservation Biology 4, 355-364.

Noss RF 2000. High-risk ecosystems as foci for considering biodiversity and ecological integrity in ecological risk assessments. Environmental Science \& Policy 3, 321-332.

O'Neill RV Gardner RH Barnthouse LW Suter GWI Hildebrand SG \& Gehrs CW 1982. Ecosystem risk analysis: a new methodology. Environmental Toxicology and Chemistry 1, 167-177.

Pascoe GA Blancher RJ \& Linder G 1996. Food chain analysis of exposures and risks to wildlife at a metals-contaminated wetland. Archives of Environmental Contamination and Toxicology 30, 306318.

Phillips A 1999. Darwin's worms. Faber and Faber London.

Posthuma L 1997. Effects of toxicants on population and community parameters in field conditions, and their potential use in the validation of risk assessment methods. In: Ecological risk assessment of contaminants in soil, eds NM van Straalen \& H Løkke, Chapman \& Hall, London, Ecotoxicology Series 5, 85-123. 
Posthuma L Boonman H Mogo FC \& Baerselman R 1994. Heavy metal toxicity in Eisenia andrei exposed in soils from a gradient around a zinc smelter (Budel) and comparison with toxic effects in OECD-artificial soil. RIVM (Dutch National Institute for Public Health and Environmental Protection) Report 719102033. PO Box 1, 3720 BA Bilthoven, The Netherlands.

Quint M 2001. Ecological risk assessment under the new contaminated land regime. In: Issues in Environmental Science and Technology No.16 Assessment and Reclamation of Contaminated Land, eds RE Hester \& RM Harrison, The Royal Society of Chemistry, London pp 103-114. Burlington House, Piccadilly, London W1J 0BA.

Robidoux PY Hawari J Thiboutot S Ampleman G \& Sunahara GI 1999. Acute toxicity of 2,4,6Trinitrotoluene in earthworm (Eisenia andrei). Ecotoxicology and Environmental Safety 44, 311321.

Robidoux PY Hawari J Thiboutot S Ampleman G \& Sunahara GI 2001. Chronic toxicity of octahydro-1,3,5,7-tetrazocine (HMX) in soil determined using the earthworm (Eisenia andrei) reproduction test. Environmental Pollution 111, 283-292.

Royal Commission on Environmental Pollution 1996. Sustainable use of soils. London, HMSO. http://www.rcep.org.uk/

Rutgers M Faber J Postma J \& Eijsackers H 2000. Site-specific ecological risks: a basic approach to the function-specific assessment of soil pollution. Wageningen. Reports of the Programme on Integrated Soil Research. Vol. 28, Programme Bureau Soil Research, Wageningen.

Saint-Denis M Narbonne JF Arnaud C \& Ribera D 2001. Biochemical responses of the earthworm Eisenia fetida andrei exposed to contaminated artificial soil: effects of lead acetate. Soil Biology and Biochemistry 33, 395-404.

Sample BE Aplin MS Efroymson RA Suter GW Welsh CJE 1997. Methods and tools for estimation of the exposure of terrestrial wildlife to contaminants. Oak Ridge National Laboratory, Oak Ridge TN. ORNL/TM-13391.

Sample BE Beauchamp JJ Efroymson RA \& Suter GW 1998a. Development and validation of bioaccumulation models for small mammals. Oak Ridge National Laboratory, Oak Ridge, TN. ES/ER/TM-219.

Sample BE Beauchamp JJ Efroymson RA Suter GW \& Ashwood TL 1998b. Development and validation of bioaccumulation models for earthworms. Oak Ridge National Laboratory, Oak Ridge, TN. ES/ER/TM-220.

Sample BE Opresko DM \& Suter GW 1996. Toxicological benchmarks for wildlife: 1996 revision. Oak Ridge National Laboratory, Oak Ridge, TN. ES/ER/TM-86/R3.

Sample BE \& Suter GW 1994. Estimating exposure of terrestrial wildlife to contaminants: draft report. Oak Ridge National Laboratory, Oak Ridge, TN. ES/ER/TM-125.

Sample BE Suter GW Efroymson \& RA Jones DS 1998c. A guide to the ORNL ecotoxicological screening benchmarks: background, development, and application. Oak Ridge National Laboratory, Oak Ridge TN. ORNL/TM-13615. May 1998.

Sample BE Suter GW Beauchamp JJ \& Efroymson RA 1999. Literature-derived bioaccumulation models for earthworms: development and validation. Environmental Toxicology and Chemistry 18, 2110-2120. 
Schaefer M 2003. Behavioural endpoints in earthworm ecotoxicology: evaluation of different test systems in soil toxicity assessment. Journal of Soils and Sediments 3, 79-84.

Scott-Fordsmand JJ Pederson MB \& Jensen J 1996. Setting a soil quality criterion. Toxicology \& Environmental News 3, 20-24.

Scott-Fordsmand JJ Weeks JM \& Hopkin SP 2000. Importance of contamination history for understanding toxicity of copper to earthworm Eisenia fetica (Oligochaeta: Annelida), using neutral-red retention assay. Environmental Toxicology and Chemistry 19, 1774-1780.

Shore RF 1995. Predicting cadmium, lead and fluoride levels in small mammals from soil residues and by species-species extrapolation. Environmental Pollution 88, 333-340.

Slobodkin LB 2000. Proclaiming a new ecological discipline. Bulletin of the Ecological Society of America 223-226.

Spellerberg IF \& Minshull A 1992. An investigation into the nature and use of ecology in environmental impact assessment. British Ecological Society Bulletin 23, 38-45.

Spurgeon DJ 1997. Extrapolation of laboratory toxicity results to the field: a case study using the OECD artificial soil earthworm toxicity test. In: Ecological risk assessment of contaminants in soil eds NM van Straalen \& H Løkke, Chapman \& Hall, London, Ecotoxicology Series 5, 253-273.

Spurgeon DJ \& Hopkin SP 1995. Extrapolation of the laboratory-based OECD earthworm toxicity test to metal-contaminated field sites. Ecotoxicology 4, 190-205.

Spurgeon DJ \& Hopkin SP 1996a. Effects of metal-contaminated soils on the growth, sexual development, and early cocoon production of the earthworm Eisenia fetida, with particular reference to zinc. Ecotoxicology and Environmental Safety 35, 86-95.

Spurgeon DJ \& Hopkin SP 1996b. The effects of metal contamination on earthworm populations around a smelting works: quantifying species effects. Applied Soil Ecology 4, 147-160.

Spurgeon DJ \& Hopkin SP 1996c. Risk assessment of the threat of secondary poisoning by metals to predators of earthworms in the vicinity of a primary smelting works. The Science of the Total Environment 187, 167-183.

Spurgeon DJ \& Hopkin SP 1999a. Seasonal variation in the abundance, biomass and biodiversity of earthworms in smelter contaminated soils. Journal of Applied Ecology 36, 173-184.

Spurgeon DJ \& Hopkin SP 1999b. Life-history patterns in reference and metal-exposed earthworm populations. Ecotoxicology 8, 133-141.

Spurgeon DJ Weeks JM \& van Gestel CAM 2003. A summary of eleven years progress in earthworm ecotoxicology. Pedobiologia 47, 588-607.

Suter GW 1993. New concepts in the ecological aspects of stress: the problem of extrapolation. Science of the Total Environment Supplement 63-76.

Suter GW 1998. Ecotoxicological effects extrapolation models. In: Risk assessment: logic and measurement, eds MC Newman \& CL Strojan, Ann Arbor Press, Chelsea, Michigan, 167-185.

Suter GW Efroymson RA Sample BE \& Jones DS 2000. Ecological risk assessment for contaminated sites. Lewis Publishers, Boca Raton. 
Swedish Environment Code 1998. Miljöbalken 1998:808, English translation Ds 2000:61. http://www.sweden.gov.se/sb/d/574/a/22847

Tunesi S \& D'Amico L 2000. The Italian legislation for the clean-up of contaminated sites. Proceedings Contaminated Soil 2000, Leipzig. Vol. 1, pp 626-634.

United States Environmental Protection Agency 1998. Guidelines for ecological risk assessment. EPA/630/R-95/002F. April 1998. http://cfpub.epa.gov/ncea/

Urzelai A Hernandez AJ \& Pastor J 2000. Biotic indices based on soil nematode communities for assessing soil quality in terrestrial ecosystems. Science of the Total Environment 247, 253-261.

van Beelen P Fleuren-Kemila AK \& Aldenberg T 2001. The relation between extrapolated risk, expressed as potentially affected fraction, and community effects, expressed as pollution-induced community tolerance. Environmental Toxicology and Chemistry 20, 1133-1140.

van Brummelen TC Verweij RA Wedzinga SA \& van Gestel CAM 1996. Polycyclic aromatic hydrocarbons in earthworms and isopods from contaminated forest soils. Chemosphere 32, 315341.

van de Leemkule MA van Hesteren S \& Pruiksma MA 1999. Minimum soil quality: a use-based approach from an ecological perspective Part 2: Immobile organic micro-pollutants. Technical Soil Protection Committee, TCB R09(1998). P.O. Box 30947, 2500 GX, The Hague, The Netherlands. April 1999.

van Hesteren S van de Leemkule MA \& Pruiksma MA 1999. Minimum soil quality: a use-based approach from an ecological perspective Part 1: Metals. Technical Soil Protection Committee, TCB R08(1998). P.O. Box 30947, 2500 GX, The Hague, The Netherlands. April 1999.

van Straalen NM 2002. Assessment of soil contamination - a functional perspective. Biodegradation $13,41-52$.

van Wensem J Faber JH van Hesteren S van de Leemkule MA Pruiksma MA \& Vegter JJ 2000. Ecological requirements in relation to land use. Proceedings Contaminated Soil 2000, Leipzig. Vol. 1, pp 171-172.

van Wensem J \& Vegter JJ 1998. Large scale heavy metal pollution: the case for an integrated risk and landuse management approach. Proceedings Contaminated Soil '98, 6th International FZK/TNO Conference, Edinburgh, UK. Vol. 1, pp 445-452.

Walton KC 1986. Fluoride in moles, shrews and earthworms near an aluminium reduction plant. Environmental Pollution 42A, 361-371.

Walton KC 1987. Factors determining amounts of fluoride in woodlice Oniscus asellus and Porcellio scaber, litter and soil near an aluminium reduction plant. Environmental Pollution 46, 1-9.

Weeks JM Spurgeon DJ Svendsen C Hankard P Kammenga J Dallinger R Köhler H-R Simonsen V \& Scott-Fordsmand J 2004. Critical analysis of soil invertebrate biomarkers: a field case study. Ecotoxicology 13, 817-822.

Whitford WG Rapport DJ \& de Soyza AG 1999. Using resistance and resilience measurements for 'fitness' tests in ecosystem health. Journal of Environmental Management 57, 21-29. 
Wilke BM 2000. Biological soil quality assessment according to the German soil protection law. Third SETAC World Congress, 21-25 May 2000, Brighton, UK. SETAC Europe, Av. de la Toison d'Or 67 B-1060 Brussels, Belgium. 


\section{Table 1 Selected international approaches to ecological risk assessment for land contamination}

\begin{tabular}{|c|c|c|}
\hline Country/basis & Limitations, benefits and features & Reference \\
\hline $\begin{array}{l}\text { Australia } \\
\text { Derivation of ecological risk-based cleanup goals to } \\
\text { protect terrestrial receptors. }\end{array}$ & $\begin{array}{l}\text { Background concentrations used as default for } \\
\text { cleanup criteria if site specific data is } \\
\text { unavailable. Ecological receptors selected to } \\
\text { include different trophic levels. Lack of } \\
\text { national policy to require criteria to be applied. }\end{array}$ & Benker et al. 2000 \\
\hline $\begin{array}{l}\text { Canada } \\
\text { Recommended Canadian soil quality guidelines; } \\
\text { interim environmental quality criteria for } \\
\text { contaminated sites; } \\
\text { Guidelines for ecological risk assessment; Protocol for } \\
\text { the derivation of soil quality criteria. }\end{array}$ & $\begin{array}{l}\text { Includes site specific data and predictive } \\
\text { modelling to derive quantitative information on } \\
\text { complex ecosystem responses including } \\
\text { chronic effects and interactions between } \\
\text { chemicals and ecosystem level studies. }\end{array}$ & $\begin{array}{l}\text { Canadian Council of } \\
\text { Ministers of the } \\
\text { Environment } 1998\end{array}$ \\
\hline
\end{tabular}

Denmark
Use of NOEC, LOEC and EC, extrapolation of
laboratory and field data with use of application
factors as a safety margin. Aim to protect function and
structure of soil.

structure of soil.
Soil protection strongly linked to groundwater protection. Funding is remediation driven. Assumes log-normal distribution. Only a fraction of species present in the ecosystem are usually covered by toxicity data. This therefore assumes that protection of those species will be sufficient to protect ecosystem function and structure.
Guideline documents on soil quality criteria. Oliebranchens Miljøpulje (petroleum tax for petroleum contamination remediation).

Technology development fund for soil and groundwater innovative remediation techniques.

Wilke 2000;

CLARINET 2001 to the anthropogenic use of the soil. Establishes what constitutes soil contamination. Soil organisms have not yet been considered. restore soil functions.
Ecological criteria not yet used in the development of MAC values.

Tunesi \& D'Amico 2000
Maximum admissible concentrations derived. If MAC values are exceeded, then the land is classed as contaminated and clean-up liability is initiated.

\section{The Netherlands}

Soil Protection Act 1994, as amended.

Suitable for use approach, $\mathrm{HC}_{50}$ applied to land use types. Maximum permissible soil concentrations defined. A log distribution of NOEC data provides species sensitivity distributions (SSD). The serious risk concentration is derived by the $50^{\text {th }}$ percentile of the SSD.

Circular on target values and intervention values for soil remediation 2000 .

In March 2004, the Dutch Government announced proposals to amend the Soil Protection Act as a result of a change in policy. If adopted, the change would result in soil remediation being carried out by combined public and private investment (present system uses public finance) to reduce the timescales involved to around one generation.

\section{Sweden}

Contaminated land assessment is related to hazard and levels of pollutants, taking into account their migration potential, site sensitivity and protective value. General framework and guideline values which do not pose unacceptable risks to the environment, to indicate the degree of contamination on a site, to develop clean-up
The Soil Protection Act aims to prevent, restrict or remedy changes of soil properties, which entail a reduction of or a threat to the functional properties the soil has for man, flora and fauna.

Assumes it is acceptable for $50 \%$ of the organisms involved to be exposed to contamination levels higher than their NOEC. Toxicity of pollutants for land use specific ecological parameters are mostly unavailable and are highly arbitrary.

Remediation is geared to the desired end use. Intervention values, indicative levels for serious contamination and target values equally apply to aquatic sediment.

Breure \& Peijnenburg 2003

Crommentuijn et al. 1997

Crommentuijn et al. 2000

Faber 1998

Netherlands Ministry of

Housing Spatial

Planning and the

Environment 1994

Netherlands Ministry of

Housing Spatial

Planning and the

Environment 2000

van Wensem et al. 2000

Policy driven by increasing acidification in SW Sweden and nutrient deficiency in forests.

Swedish Environment Code 1998 
goals and to evaluate clean-up results.

\section{Switzerland}

Swiss Ordinance Relating to Pollutants in Soil (1986)

and the Ordinance Relating to Impacts on the Soil

Adopts intervention values for guide, trigger and clean-up. Evidence of widespread

Swiss Agency for the (1998).

contamination; precautionary guide values for inorganic soil contaminants (Appendix 1 of the

Ordinance relating to Contaminants in Soil of

1st July 1998) have been exceeded in $42 \%$ of

the National Soil Monitoring Network's study

sites, primarily in topsoil. Main contaminants are $\mathrm{Pb}, \mathrm{Cu}, \mathrm{Cd}$.

UK

Tiered approach for assessing soil contaminants only on the basis of the legal definition of harm as contained in Part IIA. Uses a weight-of-evidence approach. Soil screening values used for effects assessment.

\section{USA}

Tiered approach to ecological risks associated with contaminated soil. Developing a programme to develop ecological (risk) soil screening levels as toxic reference values (Oak Ridge Toxicological Benchmarks)
Consultation framework. Existing soil screening values are limited though they are being developed.
Environment Agency 2003
Standardisation is minimised. Based mainly on characteristics and need of decision makers.

Comparable to human health risk-based screening concentration (RBC) values.
United States

Environmental

Protection Agency 1998

Sample \& Suter 1994

Sample et al. 1996

Sample et al. 1997

Sample et al. 1998a

Sample et al. 1998b

Sample et al. 1998c 
Table 2 Part IIA: Significant harm to terrestrial ecosystem receptors (Department of Environment Transport and the Regions 2000a)

\begin{tabular}{|c|c|}
\hline Type of Receptor & $\begin{array}{l}\text { Description of harm to the type of receptor that is to be } \\
\text { regarded as significant harm }\end{array}$ \\
\hline $\begin{array}{l}\text { Any ecological system, or living organism forming part of } \\
\text { such a system, within a location which is: } \\
\text { - } \quad \text { an area notified as an area of special scientific interest } \\
\text { (SSSI) under Section } 28 \text { of the Wildlife and } \\
\text { Countryside Act 1981; } \\
\text { any land declared a National Nature Reserve under } \\
\text { Section } 35 \text { of that Act; } \\
\text { any area of special protection for birds, established } \\
\text { under Section } 3 \text { of that Act; } \\
\text { any European Site within the meaning of regulation } 10 \\
\text { of the Conservation (Natural Habitats etc) Regulations } \\
\text { 1994 (i.e. Special Areas of Conservation and Special } \\
\text { Protection Areas); } \\
\text { any candidate Special Areas of Conservation or } \\
\text { potential Special Protection Areas given equivalent } \\
\text { protection; } \\
\text { any habitat or site afforded policy protection under } \\
\text { paragraph } 13 \text { of Planning Policy Guidance Note } 9 \\
\text { (PPG9) on nature conservation (i.e. candidate Special } \\
\text { Areas of Conservation, potential Special Protection } \\
\text { Areas and listed Ramsar sites); or } \\
\text { any nature reserve established under Section } 21 \text { of the } \\
\text { National Parks and Access to the Countryside Act } 1949 .\end{array}$ & $\begin{array}{l}\text { For any protected location: } \\
\text { - harm which results in an irreversible adverse change, or in } \\
\text { some other substantial adverse change, in the functioning of } \\
\text { the ecological system within any substantial part of that } \\
\text { location; or } \\
\text { - harm which affects any species of special interest within that } \\
\text { location and which endangers the long-term maintenance of } \\
\text { the population of that species at that location. } \\
\text { In addition, in the case of a protected location which is a } \\
\text { European Site (or a candidate Special Area of Conservation or a } \\
\text { potential Special Protection Area), harm which is incompatible } \\
\text { with the favourable conservation status of natural habitats at that } \\
\text { location or species typically found there. } \\
\text { In determining what constitutes such harm, the local authority } \\
\text { should have regard to the advice of English Nature and to the } \\
\text { requirements of the Conservation (Natural Habitats etc) } \\
\text { Regulations } 1994 \text {. }\end{array}$ \\
\hline
\end{tabular}


Table 3 Definition of harm: information required for a site specific risk assessment

\begin{tabular}{ll}
\hline Issue Descriptor & Information Required \\
\hline Site Designation & How complex is the basis of designation, individual or several species or type of habitat? \\
& What is/was background contamination? \\
\hline Land Contamination & Proximity, is the land causing an effect to the designated area? \\
& What are the stressors (contaminants)? \\
\hline Soil Quality & Does protection of soil quality protect ecosystem function? \\
& Are additive, cumulative and synergistic effects considered or are chemicals assessed in \\
& isolation? \\
\hline Exposure Assessment & Is there predictive capability? \\
& Is exposure occurring? \\
& What is exposed and over what duration? \\
& What are the relevant exposure and uptake routes? \\
& Where and how much exposure occurs? \\
& What is the variance and uncertainty? \\
& What is the probability of harm measured by exposure (dose response or bioavailability)? \\
& Is the harm/effect likely to be irreversible? \\
\hline Ecological Receptors & Which species? \\
& Is the use of indicator species appropriate? \\
\hline Ecological Function & Which functional process(es) is/are being affected? \\
\hline Uncertainty and Decision & What is the desired level of protection? \\
& What assumptions have been made? \\
Making & What is the relative risk versus the scientific basis/judgement? \\
& What are the consequences of harm (the effect(s))? \\
& Is there a scientific and regulatory consensus of opinion? \\
& What are the policy implications? \\
& Is the contaminated land a Part IIA site? \\
& What are the implications for remediation? \\
\hline & \\
\hline
\end{tabular}


Table 4 Selected earthworm exposure data for specific soil metal contaminants and site case studies (after Suter 1990, p.131).

Available contaminant uptake factors (soil or soil pore water concentration)

Case study location

[Various]

[Various]

Germany

Netherlands

Netherlands

Netherlands

UK, Avonmouth

UK, Cumbria \& Devon

UK, Thames Region

USA, Maryland

As, $\mathrm{Cd}, \mathrm{Cu}, \mathrm{Zn}$

$\mathrm{Cd}, \mathrm{Cu}, \mathrm{Pb}, \mathrm{Ni}, \mathrm{Zn}$

$\mathrm{Pb}$
USA, Montana

USA, Pennsylvania

Wales

\section{Reference}

Neuhauser et al. 1995
Sample et al. 1999
Emmerling et al. 1997
Hendricks et al. 1995
Ma 1982
Ma et al. 1983
Spurgeon \& Hopkin 1996a, 1996b, 1999b; Weeks et al. 2004
Langdon et al. 2001
Environment Agency 1999
Beyer et al. 1987
Pascoe et al. 1996
Beyer et al. 1982
Corp \& Morgan 1991

Note: Laboratory data has been specifically excluded. See Spurgeon et al. 2003 for a discussion on the use of laboratory and field tests. 
1 Figure 1 Development of ecosystem effects indicators (after Merkle \& Kaupenjohann 2000)

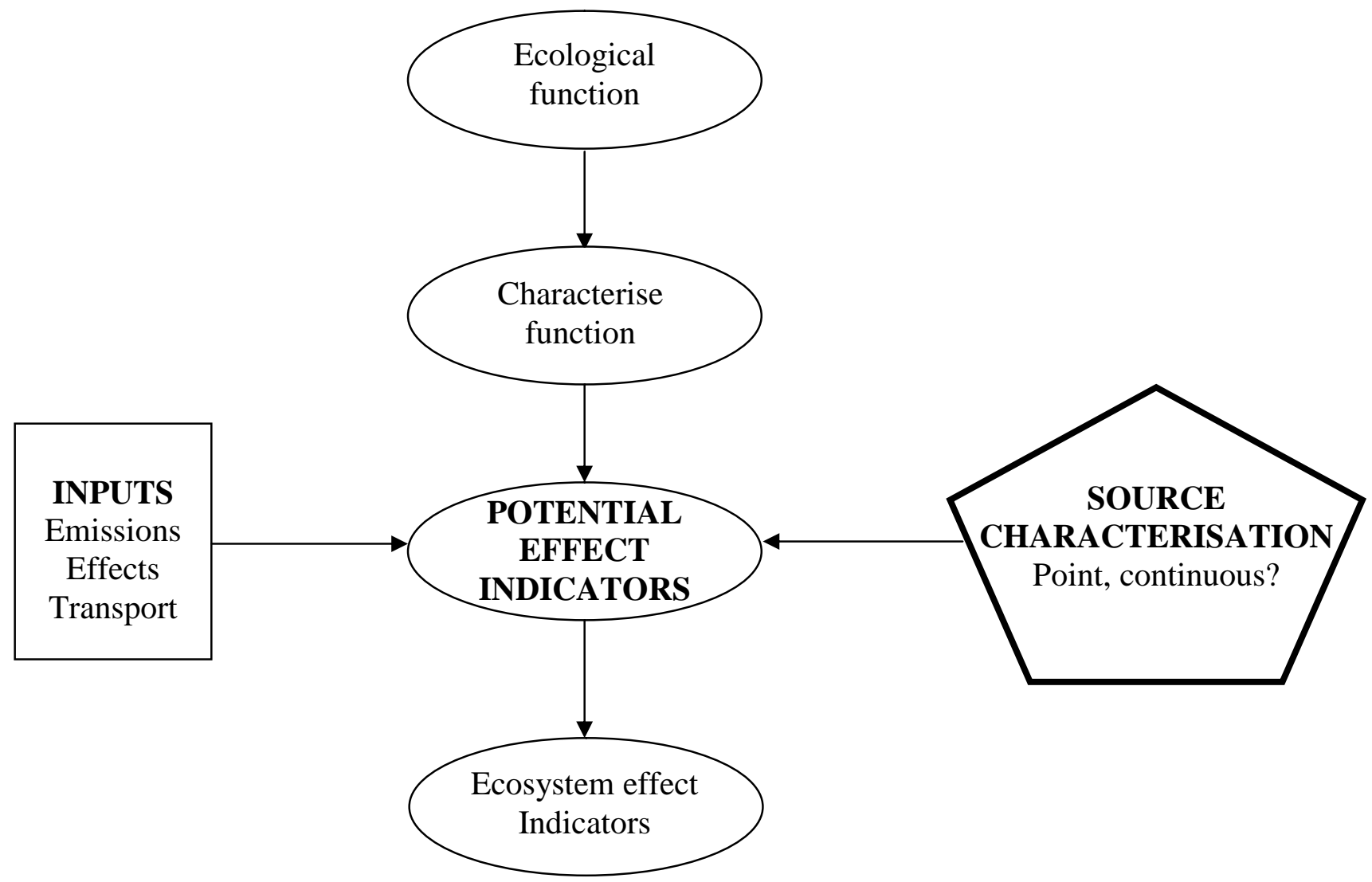

